\title{
An Assessment of Mining Activities Impact on Vegetation in Bukuru Jos Plateau State Nigeria Using Normalized Differential Vegetation Index (NDVI)
}

\author{
Musa, Haruna D. \\ Urban and Regional Planning Department, Federal University of Technology \\ Minna, Niger State \\ E-mail: musharry@yahoo.com, musaharunad@futminna.edu.ng \\ Jiya, Solomon N. \\ Department of Geography, Ibrahim Badamasi Babangida University \\ Lapai, Niger State \\ E-mail: solojiya@yahoo.com
}

Received: July 25, 2011 Accepted: October 24, $2011 \quad$ Published: December 1, 2011

doi:10.5539/jsd.v4n6p150 URL: http://dx.doi.org/10.5539/jsd.v4n6p150

\begin{abstract}
The study area has a pathetic and deplorable condition of landuse/ landcover. The vegetal cover in the area has to be removed from the activities of tin mining which consequently resulted into adverse environmental effect such as erosion. Different forms of human induced stress such as tin mining and heavy rainfall have severely degraded soils on the Jos Plateau. Such degradation problems are also caused by deforestation, inappropriate farming system, bush burning and over-grazing which are hostile to the environment. The impact of tin mining has greatly affected the natural ecology of the study area Bukuru. Micro and macro organisms and plants have been stripped off their natural habitat due to tin mining activities. This paper therefore, assesses the mining activities impact on the vegetation in Bukuru area of Jos plateau in Nigeria. Normalized Differential Vegetation Index (NDVI) techniques was adopted to Maps effect of tin mining on the vegetation for the period between 1975 and 2007 using LandSat satellite data. The result of the differential vegetation index analysis reveals a decline in vegetated surfaces in 1986 ranging from 0.04 to 0.58 indicating 0.05 and continuous loss in vegetation over the study area in 2007 (vegetated surface decrease by 0.08 between 1986 and 2007). The decrease in vegetated surface is due to intensive mining and cultivation.
\end{abstract}

Keywords: Mining, Environmental degradation, Biodiversity extinction, Deforestation, Remote sensing

\section{Introduction}

Mining and processing has led to socio-economic and infrastructural development of the Jos area, with major negative impacts on physical, biological and hydrological environments. Similar negative impacts are widespread in most other small-scale, largely illegal mining areas in Nigeria. The importance of the environment to sustainable development in any society is not in doubt. There must be a healthy, rich and adequately protected environment in order to have a healthy, prosperous society. The environment provides the foundation for all development efforts in the country. Tin mining activities which have caused considerable erosion damages to lands arising from active gully equal to $7,240 \mathrm{~km}$ in length (Sumaila, 1989). Apart from tin mining, it is obvious that such human activities like construction of highways, rail road's, pipelines, airport, industrial sites, sanitary landfills, dam reservoirs, timber harvesting, bush burning and grazing have potential and adverse effects on the environment. Environmental degradation is a very serious issue and to ignore the environment, is to ignore our humanity and surrender its race that is entirely dependent on it. There is the need to manage the ecosystem responsibly so that those coming after will not have to complain, worry or curse their ancestors.

The influxes of mining operators without adequate monitoring of production and documentation do not augur well for conservation of vegetation cover, minerals and land use systems. The study area is characterized by abandon 
mining ditches, from mining the tin ore. Also, the erosion in the study area is on the increase leading to the rejuvenation of valleys probably due to deforestation, overgrazing, bush burning and possible isocratic uplift.

Most importantly, the mineral exploitation provided a good source of revenue. But in spite of these enumerated economic benefits, mining activities in the study area had adverse effect on landuse / landcover. The study area vegetation cover had been cleared by the aggressive tin miners who had one goal dig out tin no matter what happens to the land in the process. Quite obviously, within a short time, the green vegetation of the region had given way to bare sand.

Today, the study area has a pathetic and deplorable condition of landuse / landcover. The vegetal cover in the area has to be removed from the activities of tin mining which consequently resulted into adverse environmental effect such as erosion. Udo (1981) argued that the large increase of population on the plateau cannot be said to have aggravated the pressure on farmland except that soil impoverishment and soil erosion induced by over-grazing have rendered some land unsuitable for cropping. But the soil impoverishment, erosion and over-grazing are also caused by growing human population. Much of the Jos plateau's land is environmentally delicate and easily damaged, and large areas are already seriously degraded (Formeny, 1977). Different forms of human induced stress such as tin mining and heavy rainfall have severely degraded soils on the Jos Plateau. Such degradation problems are also caused by deforestation, inappropriate farming system such as unscientific combination of crops in mixed cropping, ridging along slopes, annual burning of vegetal cover, nutrient removal by crops without replenishment and over-grazing which are hostile to the environment (Olowolafe, 1997). This paper therefore, assesses the mining activities impact on the vegetation in Bukuru area of Jos plateau in Nigeria.

\section{The Effect Deforestation and Mining Activities}

In the words of Ehrlich et al. (1977) "Humanity shares the Physical vehicle of earth with an enormous diversity of other living-things plants, animals and micro-organisms" which constitute a living web (biological community) encased in a finite physical environment (abiotic elements). The intelligent application of technology fosters human well being directly. Human history is said to be "largely written in terms of the struggle between man and nature over the terms of man's existence" (Barkley \& Seckler, 1972). The destruction of the natural vegetation in a given area resulting from mining activities may increase flood Peaks and Sediment load on a given stream flow.

Identification of vegetation from remote sensing data gives a lot of information about erosion as it indicates decreased run-off due to interception and evaporation, increased infiltration, and increase stream flow due to decrease evapotranspiration and interception. Again, stream side vegetation slows down flood water passage and retard stream-bank erosion due to root binding (Edward, 1992). Conventional Photographs are very useful in interpretation and monitoring vegetation and it changes (Poulton, 1977), yet satellite imageries proved to be a very valuable tool for studying various aspects of vegetation such as vegetation character (Helden, 1985), vegetation changes (Hayes \& Cracknel, 1991), vegetation degradation (Roger et al., 1985; NOAA, 1984; Adeniyi, 1982; Khouria, 1993; Onyebuchi, 1985) and percentage cover of vegetation (Osterlund, 1992).Satellite sensors are capable of discerning many of the changes in Physiognomy characteristics of vegetation through spectral radiance measurement. The visible infrared bands on the Satellite multispectral sensors allow monitoring of the greenness of the vegetation. The green vegetation is highly absorbing in the visible part of the Spectrum (Halilu, 1993) and low absorbing in near infrared part due to Chlorophyll and water content and scattering caused by the leaf's internal spongy mesophyll layer (Myers, 1983).

Deforestation is a globally acclaimed problem, and a historical analysis of environmental change since the $2^{\text {nd }}$ world war made the incisive and gloomy statement: "We are moving into a period of chronic, global and extremely complex syndromes of ecological and economy interdependence. These emerging syndromes threaten to constrain and even reverse progress of human development. They will be manageable, if at all, only with a commitment of resources and constituency of purpose that transcends normal cycles and boundaries of scientific research and political action (Clark \& Holling, 1985)".

The consequences of deforestation on the Plateau region due to mining are diverse with various environmental and economic implications. It has led to the loss of forest products, flooding and erosion, aggravation of desertification and pollution, high rate of siltation of streams, decline of biological diversity and acceleration of extinction of the Plateau region flora and Fauna. The increase in carbon dioxide and temperature of the atmosphere, regulation of nutrient cycles of carbon dioxides and Photosynthesis, shifting in population provision of income through the sale of fuel wood/firewood, increased rate of evaporation and alteration of fluvial competence and capacity(Mustafa, 2010). In the Guardian (1994), the United Nations and president Clinton of USA warned on environmental crises especially on the adverse effects of destruction of tropical rain forests. In the report, the United Nation Environmental Programme (UNEP), Global Environment Outlook 2000, stated that the continued poverty of the 
majority of the planet inhabitants and excessive consumption by the majority is the two major causes of environmental degradation such as deforestation and mining activities. The report also recommended that the developed world must cut its use of natural resources by $90 \%$ to give the rest of the world a chance to emerge from poverty. The United Nation Food and Agricultural Organization (FAO) also stated that, more than 500 million acres of land in the developing countries were lost to deforestation from 1980 to 1985 (New Nigeria Newspaper, 2000). A United Nations report also stated that most of the forests cleared for agricultural use cannot sustain agriculture for very long time because the nutrients in the vegetation are not in soil due to human activities such as mining.

\section{Remote Sensing Application in Landuse/landcover Change Detection}

Remote sensing has been applied to various management issues to minimize erosion and soil degradation (Howard, 1977). This is because remote sensing provides classification of landscape with identified areas susceptible to erosion and can also be used to map stream and river courses. Ademola and Soneye (1993) used remote sensing and Geographic Information System (GIS) techniques to map the landuse and landcover in the Sokoto River north western Nigeria. In the studies of some effect of Tiga dam in Kano State, on the environment downstream, Olofin (1980) identify erosion and flood plain formations that resulted in land degradation from aerial photographs. Adeniyi (1985) states that one of the most common uses of remote sensing techniques is in land-use identification and changes. Vestappen (1977) observed that land system mapping from small scale imageries such as land-sat and radar may prove more useful than contour maps for general planning purpose, particularly in a very large region at a time. This is not in line with Jeje's (1986) assertion that band 5 of land-sat imageries appears to be very useful for land-degradation mapping purposes, but radar is less suitable for land-use mapping. Data from both spot and land-sat satellites are available in either photographic or digital form. In photographic form, images are available as prints or transparencies and in various scales. An advantage of photographic imagery is the simplicity and very low cost of interpretation tools required (simple light table or projection device). With digital information, users require computer based image analysis system to manipulate and interpret the information. However, these digital systems offer great power and flexibility and can aid in image enhancement, multitude image registration, registration with digital map and digital image classification. A view to the future and providing a competitive edge, the need for highest quality information will routinely use the data from satellite and airborne sensors to perfect their activities, digital analysis system now exist for personal computer system, augmented with colour monitors and suitable software. More interactive devices using computer based geographical information systems will facilitate the use of combined data sets, such as soils or cadastral maps (static sets) and remote sensing data as a source of up to date information on changing elements, such as land use and agricultural practices. Such systems will clearly facilitate planning and decision making for those working in agricultural fields. Campbell (1983) made a comprehensive approach to land use studies and discovered map between two time periods is usually produced to understand the changes. Adeniyi (1980) presented a good example of how change detection using sequential aerial photography was carried out in Lagos, Nigeria. Adefolalu (1986) used a combination of SLAR and LANDSAT data with ground truth observations to study West Africa and Nigeria land-use vegetation situation. Paul et al (1988) used enhanced classification approach from landsat MSS data sets (1975-1984) in assessing natural and man induced changes in land use/land cover in the semi arid environment of north Western Nigeria after construction of Bakolori Dam and reservoir. It was evident that these results of an overlay enhancement of band 5 images provided the most accurate identification or spectral changes. Okhimanhe (1993) studied land use and land cover changes in Burunburun/Tiga area in Kano state using aerial photographs of 1974 and spot HRVI of 1986 to detect the changes. Barnie and Gauld (1982) found Synthetic Aperture Radar (SAR) to be more useful than aerial photographs to land cover survey of Scotland. Patrick (1993) argued in favour of aerial photographs in monitoring land use and changes of Taraba State.

Carter (1958) used aerial photographs to identify agricultural land use, sheet and gully erosion affecting River Njaba resulting from the nature of slope, run-off and human activities such as deforestation farming and mining. Gerald (1982) used panchromatic, black and white infrared photographs to map erosion in some agricultural land in South Africa and observed that high spectral sensitivity of panchromatic photographs are very good for cultivated and uncultivated areas. The satellites carry various sensing systems capable of viewing the earth below. These systems acts like cameras measuring light reflected from the surface of the earth in different colours or spectral regions. Because agricultural crops and land use features reflect light in different ways, they can often be identified and characterized from the satellite images. Some crops are relatively easy to identify such as winter wheat in Western Canada and corn with Potatoes in the East. Crop identification; however depends on general the stage of growth and on the crop condition. NOAA has launched a series of weather Satellites that carry an imaging system called the advanced very high resolution radio meter (AVHRR). This instrument can image every 
agriculturally significant region of the globe daily, at a resolution of $1.1 \mathrm{~km}$, to provide information on vegetation condition and density. AVHRR images collected in early August of 1983 and 1984 are presented as false - colour infrared images in which the areas of better vegetation growth are represented by the brighter red tones progressing from these bright red through less reddish shades to blue tones represents a change from areas of bush vegetation to areas of sparser vegetation growth, poorer plant development and lower potential yield.

The development of vegetation indices from satellite images, on the other hand, have facilitated the process of differentiating and mapping vegetation by providing valuable information about structure and composition. Vegetation Index" (NDVI), the most commonly used vegetation index, has being satisfactorily related to functional characteristics of vegetation, particularly with the fraction of photosynthetically active radiation intercepted by vegetation, and consequently with primary productivity (Paruelo et al., 1997). Long term series ( $\sim 20$ years) of NDVI data, generated from coarse spatial resolution sensors, are valuable tools for the detection of both temporally discrete changes, like forest clearing, as well as gradual changes such as long term precipitation decline (Heumann et al., 2007; Hansen \& DeFries, 2004).

In tropical dry forests, the Normalized Difference vegetation Index (NDVI) from Landsat has demonstrated to be an indicator of overall green biomass, canopy closure, tree density, and tree species diversity (Oza et al., 1996; Sanches-Aofelia et al., 2003; Krishnawsamy et al., 2004; Feeley et al., 2005), and thus, it seems a promising tool for studying the vegetation of Bukuru.

\section{The Study Area}

The Jos Plateau lies in the middle belt of Nigeria. It is approximately $104 \mathrm{~km}$ (65 miles) from North to South, and $80 \mathrm{~km}$ (50 miles) from east to West covering an area of $8,600 \mathrm{~km}^{2}$. The Jos Plateau has steep escarpment edges with a descent of about $600 \mathrm{~m}$ to the surrounding plains. The Southern part of Jos Plateau is in the Benue Lowlands extending towards the River Benue flood plain. Jos Plateau is situated between latitudes $10^{\circ} 11^{\prime} \mathrm{N}$ and $8^{\circ} 55^{\prime} \mathrm{N}$ and longitude $8^{\circ} 21^{\prime} \mathrm{E}$ and $9^{\circ} 30^{\prime} \mathrm{E}$ (Figure 1). The study area (Bukuru-Jos) lie between latitudes $8^{\circ} 50^{\prime} \mathrm{N}$ and $9^{\circ} 00^{\prime} \mathrm{N}$ and longitude $9^{\circ} 45^{\prime} \mathrm{E}$ and $9^{\circ} 50^{\prime} \mathrm{E}$. It is about $8 \mathrm{~km}$ away from Jos town and has total land area of $22 \mathrm{~km}^{2}$; it was formally dominated by mining activities in areas such as Maiadiko, Gold and base settlements, etc. It has an average elevation of about 1,150 metres above mean sea level and the highest peak some $20 \mathrm{~km}$ eastwards from Jos-shere hill, rising to 1777 metres above mean sea level (Morgan, 1979 ed.).

\section{Materials and Methods}

\subsection{Data Description}

Materials used for this research are time series satellite data from Landsat MSS satellite image acquired in November 1975, Landsat TM satellite image acquired in October 1986 and Landsat ETM+ acquired October 2007. Field data and maps of Jos plateau area. The imageries were obtained from the National Centre for Remote Sensing, Jos. Other data used include topographic map where terrain information was deduced.

\subsection{Analysis of Remote Sensing Data: Image Processing}

The following procedures were adopted in the image processing phase. This include: Pre-processing: Geometric correction and image enhancement, and Image classification (unsupervised and supervised). Different methods and techniques have been used in the procedure for image restoration, enhancement and classification in this study. These steps are described as follows (Figure 2).

\subsubsection{Unsupervised Classification}

The false colour image was used for unsupervised classification (Cluster) which was used for ground truthing. The cluster was produced using Idrisi Image Processing Module and Sub-Module Cluster using a broad generalization level set, to maximum number of six (unsupervised classes). Unsupervised classification was carried out in order to generate possible cluster to give the researcher an idea of changes and their relative types in the study area.

\subsubsection{Supervised Classification}

The study area was extracted, and stratified approach adopted to generate landuse / land cover map from digital classification of LandSat ETM+ acquired in 2007, LandSat ETM+ data acquired in 2007, landsat TM of 1986 and LandSat MSS acquired in 1975. The first step was to perform linear contrast stretch of the bands respectively to enhance the quality of features. The ETM+ bands with $30 \mathrm{~m}$ pixel size were combined in order to select the most suitable band combination. The enhanced false colour composite of bands depicting the vegetation was chosen for supervised classification using maximum likelihood (MXL) mode with necessary ground truth information. Information gathering during the site visits pertaining to landuse/landcover substantiate for the training sites. This analysis offers the changing trends in landuse/landcover patterns of the study area which reflect the derelict mining 
ponds and extent of degraded environment. In total, five land use/cover classes were adopted for the study; Urban or built up land, arable land, degraded land, Water /Mining pond and Forest land

\subsubsection{Normalize Differential Vegetation Index (NDVI)}

Normalize Differential Vegetation Index (NDVI) of the study area was calculated from the visible and near-infrared light reflected by vegetation. Healthy vegetation absorbs most of the incoming visible light, and reflects a large portion (about 25\%) of the near infrared (NIR) light, but a low portion in the red band (RED). Unhealthy or sparse vegetation reflects more visible light and less NIR light. Normalize Density Vegetation Index (NDVI) data provide an opportunity to assess quantitatively and qualitatively the vegetation cover status in the past and present, to determine trends, and to predict the ecosystem processes (Nemani et al., 1997). Result from average greenness can be applied for inter-annual assessment of vegetation cover status over the study area and give the opportunity to compare and predict for each year in terms of vegetation growth, stress and productivity. For making the NDVI following formula would be adopted:

$$
\text { NDVI }=(\text { NIR-RED }) /(\text { NIR }+ \text { RED })
$$

Calculation of NDVI for a given pixel always results in a number that ranges from minus one (-1) to plus one $(+1)$ : Bare soils give a value close to zero and very dense green vegetation have values close to $+1(0.8-0.9)$. The NDVI technique was adopted to assess the possible effect of Tin mining on vegetation over the years in the study area.

\section{Analysis and Result}

\subsection{Normalized Differential Vegetation Index (NDVI)}

Normalized Differential Vegetation Index (NDVI) Maps for the period between 1975 and 2007 were generated to help assessing the vegetation condition and to determine the extent to which mining activity affected the vegetation. The NDVI Map generated from LandSat MSS of 1975, reveals the vegetation index of the study area for this period. The non- vegetated surfaces (bare soil) covers between -0.95 to -0.06 , while the vegetated surfaces covers the range of 0.04 to 0.63 (Figure 3), indicating significant level vegetation coverage in the study area for this period.

The NDVI Map below shows decline in vegetal cover in 1986 (Figure 4). The result of the differential vegetation index analysis reveals that the vegetated surfaces ranging from 0.04 to 0.58 indicating 0.05 decrease in vegetated surface due to intensive mining and cultivation.

Further changes were observed from the NDVI analysis in the study area in 2007. The result reveals continuous loss in vegetation over the study area (Figure 5). It shows that the vegetated surface has further decrease by 0.08 between 1986 and 2007 (i.e. $0.04-0.50$ ). Further decrease in vegetation is due to intensive mining as well as extensive cultivation which exposes the soil to adverse erosion and subsequent environmental degradation.

\section{Discussion}

\subsection{Differential Vegetation Index (DVI): Vegetation Condition: 1975 - 2007}

Analysis of vegetation and detection of changes in vegetation patterns are keys to natural resources assessment and monitoring. Thus it comes as no surprise that the detection and quantitative assessment of green vegetation is one of the major applications of remote sensing for environmental resource management and decision making. NDVI measurement has the desirable property ranging from -1 to +1 with 0 representing the approximate value of no vegetation. Thus negative values represent non-vegetated surfaces.

In 1975 , non-vegetated surfaces ranges between -0.95 to -0.06 , while the vegetated surfaces ranges from 0.04 to 0.63 (Figure 3) indicating substantial level greenness in the study area for this period. This however, declined in 1986 (eleven years period). The result of the analysis shows that the vegetated surfaces ranges from 0.04 to 0.58 (Figure 4 ) indicating 0.05 decrease in vegetated surface.

Further changes were observed between 1986 and 2007 (nineteen years of mining period), which reveals continuous loss in vegetation in the study area. It is observed that the vegetated surface has further decrease by 0.08 between 1986 and 2007 (Figure 5). Further decrease is noticed in vegetation is as a result of intensive mining as well as extensive cultivation, this exposes the soil to erosion and subsequent environmental problems (Figure 6).

\section{Conclusion}

The impact of tin mining has greatly affected the natural ecology of the study area Bukuru. Micro and macro organisms and plants have been stripped off their natural habitat due to tin mining activities. The removal of organic rich surface soils required for agricultural and human settlement results in change in land use. The absence of natural vegetation has greatly increased the menace of gully erosion in mining areas. Man has contributed to this 
cause by clearing the vegetation for firewood and agricultural practices therefore leaving the land bare by making it susceptible to erosion. Also, the overstocking of pasture from overgrazing, bush burning and removal of vegetation cover with the trail of footpaths of animals invariably become channels of erosion.

\section{Recommendations}

Results of the study show that mining activities have significant effects on the environment. Especially in Bukuru areas these effects have not seriously taken into consideration. Although mining activities should be organized sustainable manner. Most mining activities have been executed illegally. The following recommendations were made in view of the findings. They are:

(1) The distribution and expansion of mining sites should be monitored, their environmental damages should be determined; mitigation studies against these damages should be performed, and regular inspections should be executed to keep these activities under control.

(2) Modern technologies should be used to obtain more effective results from these studies. Although monitoring the changes in large areas by using conventional method is very difficult, remote sensing is the most convenient technique to collect a large amount of data for this kind of areas. With the ability of satellite data, it is possible to detect and analyze the magnitude and spatial changes of natural environment which is significant for resource managers.

(3) Additionally, GIS technique should be adopted and used to summarize changes in the spatial distribution of land use/land cover classes by overlaying map of different dates and analyze their spatial coincidence to help in decision making process in order to project future land development for the study area and reduce the possible environmental problems.

\section{References}

Adefolalu, D. O. (1986). Regional studies with satellite data in Africa on desertification of the Sudan Sahel both in Nigeria in Proc ISLSCP Con. Rome Italy (Ero Ife. Ed.): 430 - 439.

Ademola, O. O. \& Soneye, A. R. (1993). Land use Map Accuracy Criteria. Journal of Photogrammetry Engineering and Remote Sensing. 48 (4), 671-677.

Adeniyi, P. O. (1980). Land use change analysis using sequential aerial Photography and Computer techniques, Photogrammetric engineering and Remote Sensing. Journal of Photogrammetry Engineering and Remote sensing. 46 (2), 47-64.

Adeniyi, P. O. (1985). Land use Change Analysis using Sequential Aerial Photogrammetry Engineering and Remote Sensing. A paper presented at the $22^{\text {nd }}$ International symposium on remote sensing; Accra, Ghana.

Adeniyi, P. O. \& Sonoye, A. S. O. (1988). Using remote sensing to Evaluate the impact of Dam Construction in Northwestern Nigeria 22 International Symposium on Remote Sensing of Environment. Abidjan Cote D Ivoire.

Barkley, P. W. \& Seckler, D. W. (1972). Economic Growth and Environmental Decay: The Solution Becomes the Problem Harcourt Brace Jovanovich New York. American Scientist. 84, 166-178.

Barnie, R. V. \& Gauld, J. M. (1982). A major European experiment on the Application of Synthetic Radar (SAR) for Resources surveys and Agricultural Monitoring Applications. Soil Survey and Land Evaluation. 2 (1), 20.

Campbell, J. B. (1983). Mapping the aerial imagery for land use information, Resource Publications in Geography Association of American Geographers Washington D.C.

Carter, J. (1958). Erosion and sedimentation from Aerial Photographs. Journal of Tropical Geography, II, 31.

Clark, W. C. \& Holling, C. S. (1985). Sustainable Development of the Biosphere: Human Activities and Global Change (pp 474 - 490). Cambridge: Cambridge University Press.

Cracknell, A. P. \& Hayes, L. W. B. (1991). Introduction to Remote Sensing (pp 73-82). London: Taylor and Francis.

Edward, Keller. (1992). Environmental Geology (pp 74 - 90). U.S.A: Macmillan Publishing Company.

Ehrlich, D., Estes, J. E. \& Singh, A. (1977). Eco-Science: Population, Resources and Environment (pp 213). W. H. Freemen \& Co; San Francisco.

FAO/UNDP. (1979). Nigerian Forest Development: The establishment of Cartography printing IRS in the Federal Department of Forestry. Technical Report 4: SF/NIR 546. 
Farmeny Research (Nig.) Enterprises. (1977). An Environmental Baseline Study and Plan for Community-based Soil Erosion Control Projects in Plateau State. A Proposal submitted to Federal Environmental Protection Agency on World Bank assisted EMP Part C. (pp 30).

Feeley, K. J., Gillespie, T. W. \& Trborgh, J. W. (2005). The utility of spectral indices from Landsat ETM+ for Measuring the Structure and Composition of Tropical Dry Forests. Biotropica. 37, 508-519. http://dx.doi.org/10.1111/j.1744-7429.2005.00069.x

Gerald, G. G. (1982). Mapping erosion with air Photos Panchromatic or Black and white infrared.I.T.C.Journal. 3, 309-312.

Halilu, A. S. (1993). Identification of Potential Zones of shallow aquifers Niger State Using SPOT Satellite remote Sensing. M.Tech, thesis Federal University of Technology,Minna. Niger State.

Hansen, M. C. \& DeFries, R. S. ( 2004). Detecting long-term global forest change using continuous fields of tree-cover maps from 8-km Advanced Very High Resolution Radiometer (AVHRR) data for the years 1982-99. Ecosystems. 7, 695-716. http://dx.doi.org/10.1007/s10021-004-0243-3

Hayes, I. \& Crackwell. (1984). Vegetation Depiction by AVHRR .A Scottish sampling satellite Remote Sesning. International Journal of Remote Sensing. 26, 2527-2547.

Heumann, B. W., Seaquist, J. W., Eklundh, L. \& Jönsson, P. (2007). AVHRR derived phenological change in the Sahel and Soudan, Africa, 1982-2005. Remote Sensing of Environment. 108, 385-392. http://dx.doi.org/10.1016/j.rse.2006.11.025

Howard, J. A. (1977). Satellite remote Sensing of Agricultural Resources for Developing Countries. An international Perspective. Jones, R.G.London. (pp 16).

Jeje, L. K. (1986). Terrain analysis with special preference to Landsat and RADAR imagery, Nisor Publication. 2, 49-73.

Khouria, I. (1993). Vegetation and landuse changes in a Kana Forest Ecosystem. Journal of Nigeria Society of Remote Sensing. Maiden Edition. 1 (1), 76 - 80.

Krishnaswamy, J., M. C. Kiran \& K.N. Ganeshaiah. (2004). Tree model based eco-climatic vegetation classificatiom and fuzzy mapping in diverse tropical deciduous ecosystems using multi-season NDVI. Remote Sens. Environ. 25, 1185-1205.

Mustafa, M. (2010). Seasonal Change in the Greenness of Soybean Leaves: Groundtruthing of NDVI; research presented to Illinois Junior Science and Humanities Symposium at Southern Ill. Univ. at Carbondale.

Myers, V. I. (1983). "Remote Sensing application in Agriculture" Manual of Remote Sensing(ed.) R. N. Colwel $2^{\text {nd }}$ Edition, Vol. II American society of Photogrammetry, virgina. (pp 215-224).

NOAA. (1984). Land sat data users notes. NOAA land set Customer services Mundt Federal Building SUOUX falls USA.

Olofin, E. A. (1980). Some effects of the Tiga dam on the environment downstream in the Kano river basin.Unpublished $\mathrm{PhD}$ thesis Bayero University Kano.

Olowolefe, E. A. (1997). Distribution, Characteristics and landuse potentials of soil developed in Volcanic parent materials on the Jos Plateau. Nigeria Journal of Social and Management Studies. 4, 153-165.

Onyebuchi, C. C. (1985). Trends and prospects for the development of remote sensing in Nigeria. Journal of the Nigerian society of remote sensing. 1 (1), 14-19.

Okhimamhe, A. A. (1993). Assessment of environmental impacts on dam construction in Nigeria, a case study of Tiga dam in Kano State. An Unpublished M.Tech thesis FUT Minna.

Osterlund, H., Rosenqvist, A. \& Engberg, A. (1992). Remote Sensing for Forest Management - the Swedish ISY contribution projects. Paper Presented at the XVII ISPRS Congress, Commission VII, August 2-14.

Oza, M. P., Srivastava, V. K. \& Devaiah, P. K. (1996). Estimating tree volume in tropical dry deciduous forest from Landsat TM data. Geocarto Int. 11, 33-39. http://dx.doi.org/10.1080/10106049609354559

Paruelo, J. M., Epstein, H. E., Lauenroth, W. K. \& Burke, I. C. (1997). ANPP estimates from NDVI for the central grassland region of the United States. Ecolog. 78, 953-958. http://dx.doi.org/10.1890/0012-9658(1997)078[0953:AEFNFT]2.0.CO;2 
Patrick, S. (1993). Application of Photographic Remote Sensing system for Identifying features of Gully erosion in the Guinea Savannah Area of Taraba State, Nigeria. Journal of the Nigerian society of remote sensing. 1 (1), 26.

Poulton, E. C. \& Sessle B. J. (1977). Use of Conventional Panchromatic Aerial Photographs in range Monitoring and range resource inventory, evaluate and monitory. Manual of Remote Sensing. 453-455.

Roger, S. O. \& Brown, J. W (1985). Preliminary results of author Pogeric Albedo Changes over the past fifteen years in Eastern Canada. Proceedings of SLSCP Conference Rome. 97-99.

Sanchez-Azofeia, G. A., Castro, K. L., Rivard, B., Kalascka, M. R. \& Harris, R. C. (2003). Remote sensing priorities in tropical dry forest environments. Biotropica. 35, 134-142.

Sumaila F. A. G (1989). Accessibility and Rural Development, Relationships in the Tin mining Region of the Jos Plateau. Main Report September, Published by Authority, 9(2), Jos $11^{\text {th }}$ November. Jos: Government Printer. (pp 31).

Verstappen, H. T. (1977). Remote Sensing in Geomorphology. Elseviers, Amersterdam. 24.

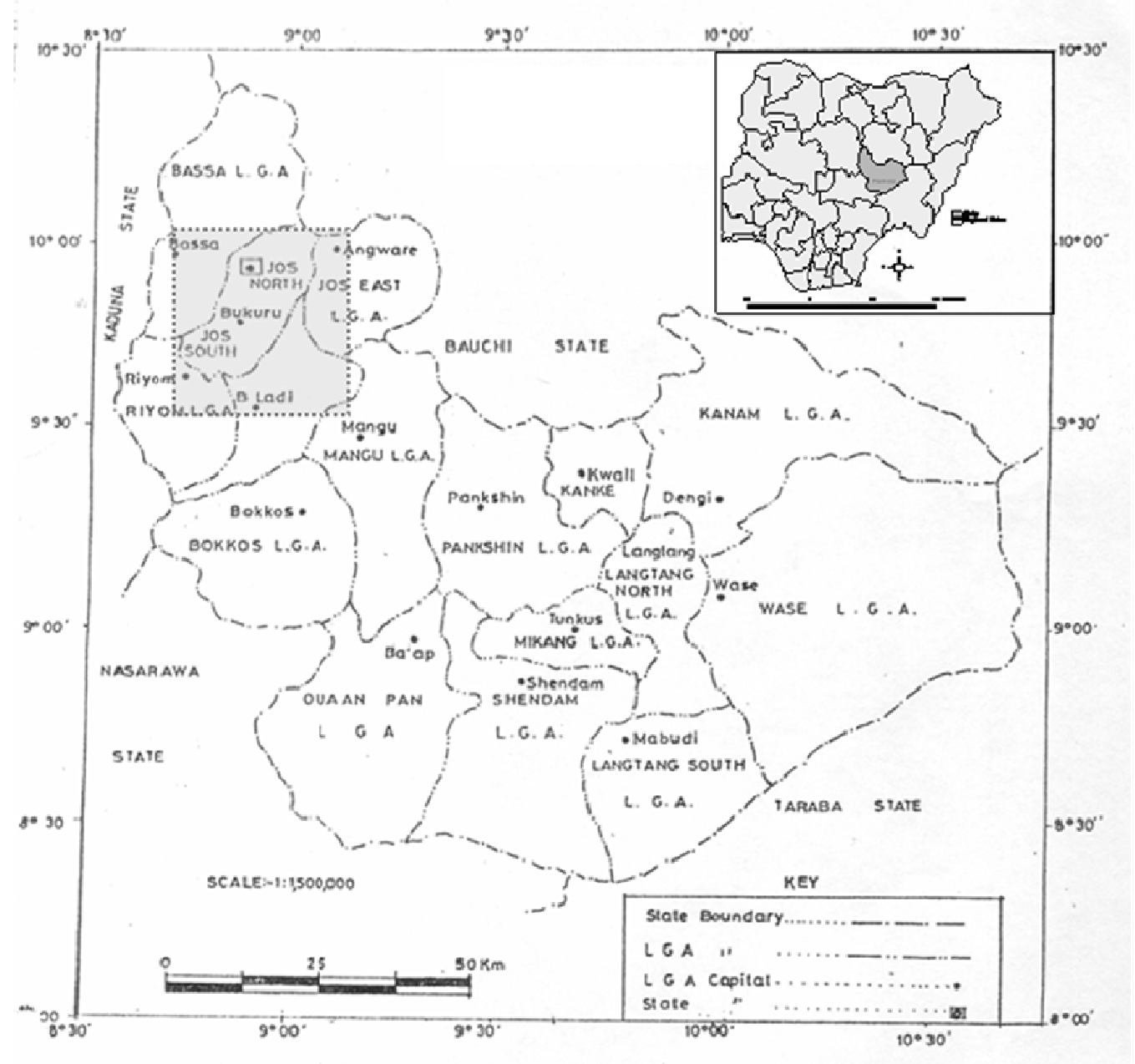

Figure1. The Location of Jos - Bukuru, Plateau State 


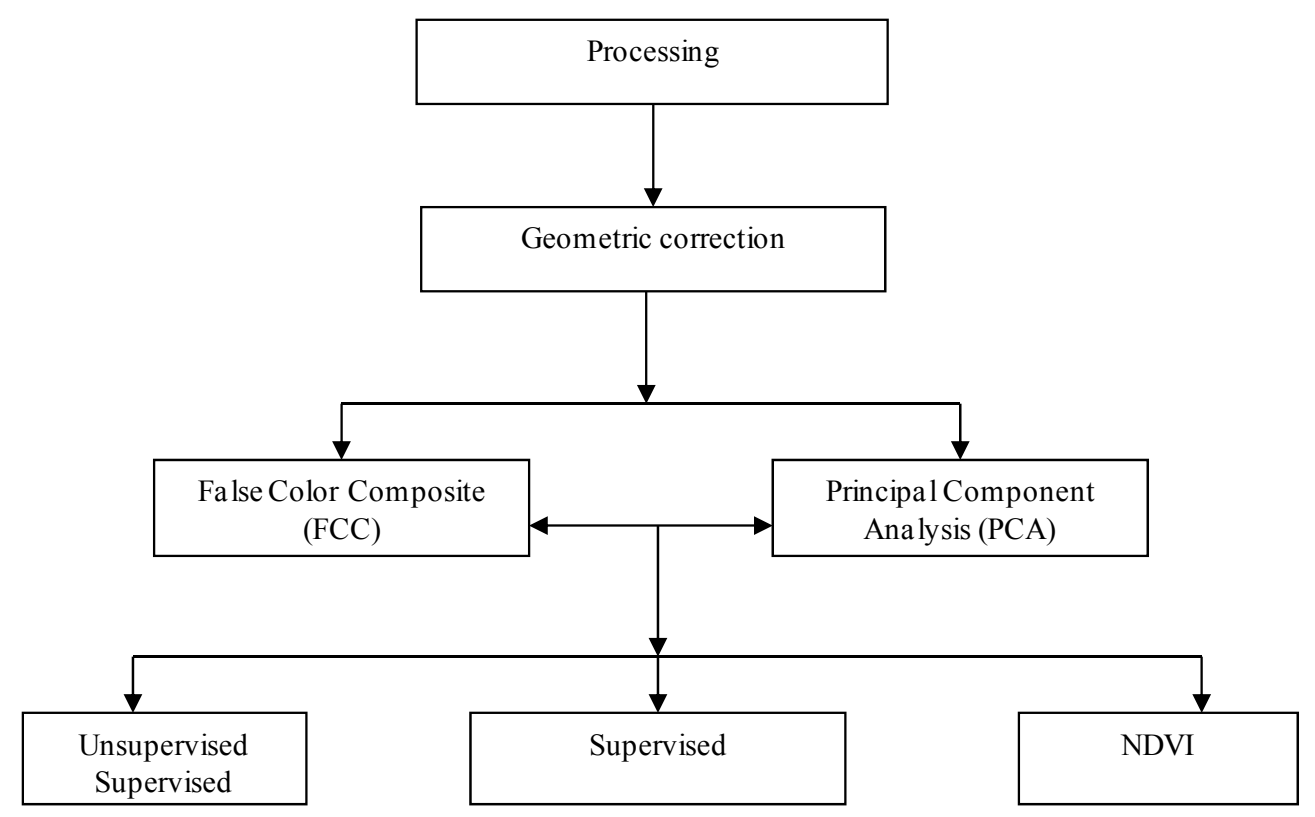

Figure 2. Image classification procedure

Source: Author's compilation

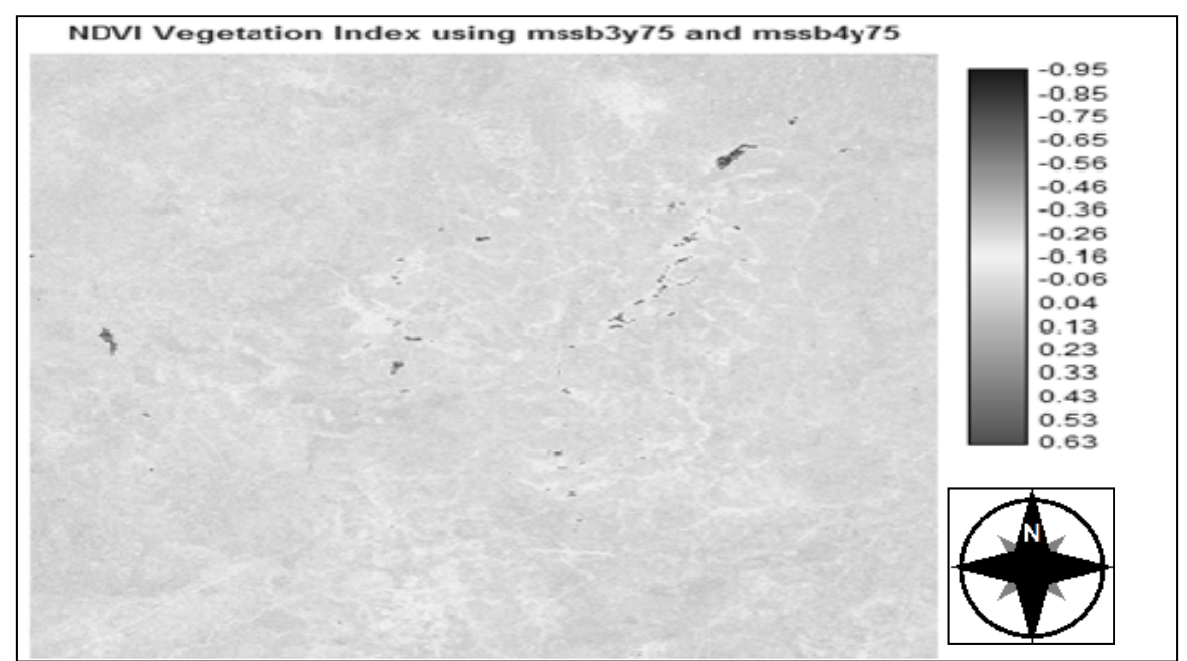

Figure 3. Pre-Mining condition of vegetation Index (greenness) from LandSat MSS 1975 


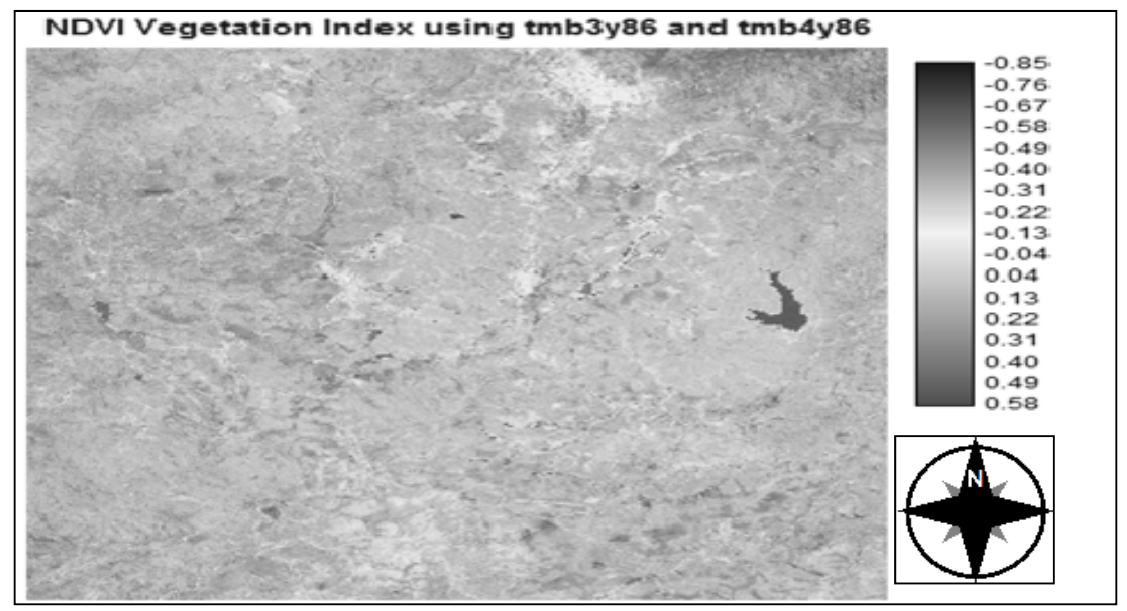

Figure 4. Post-Mining condition of vegetation Index (greenness) from LandSat TM, 1986

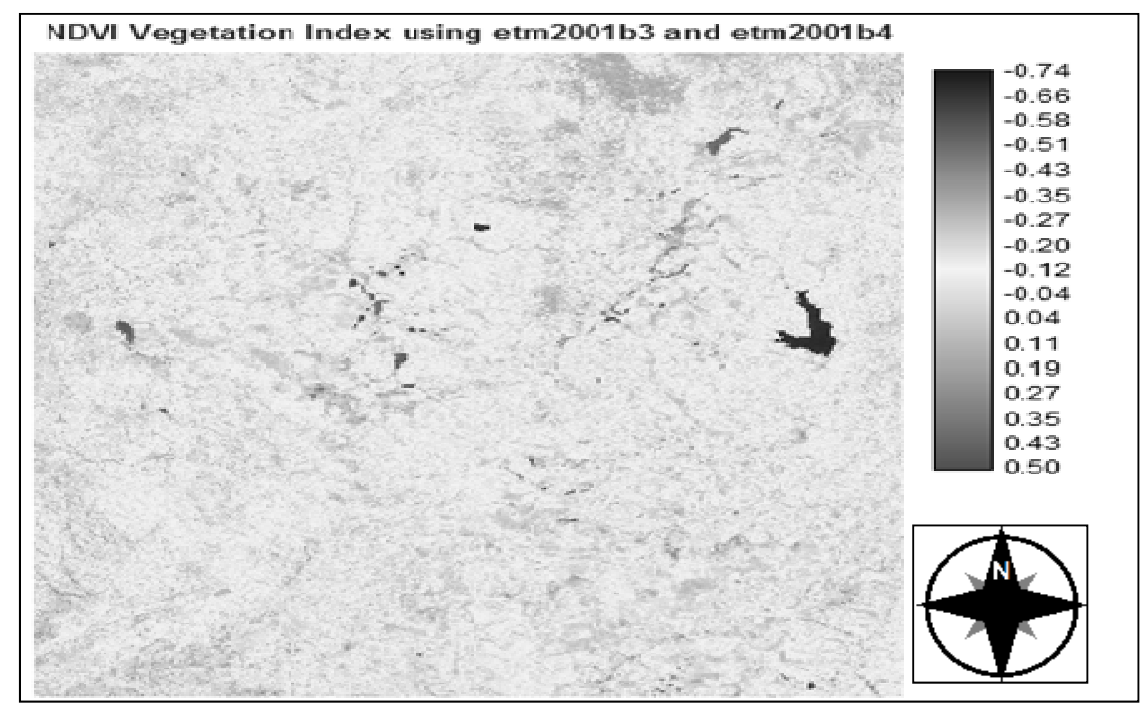

Figure 5. Post-Mining condition of vegetation Index (greenness) from LandSat ETM+, 2007

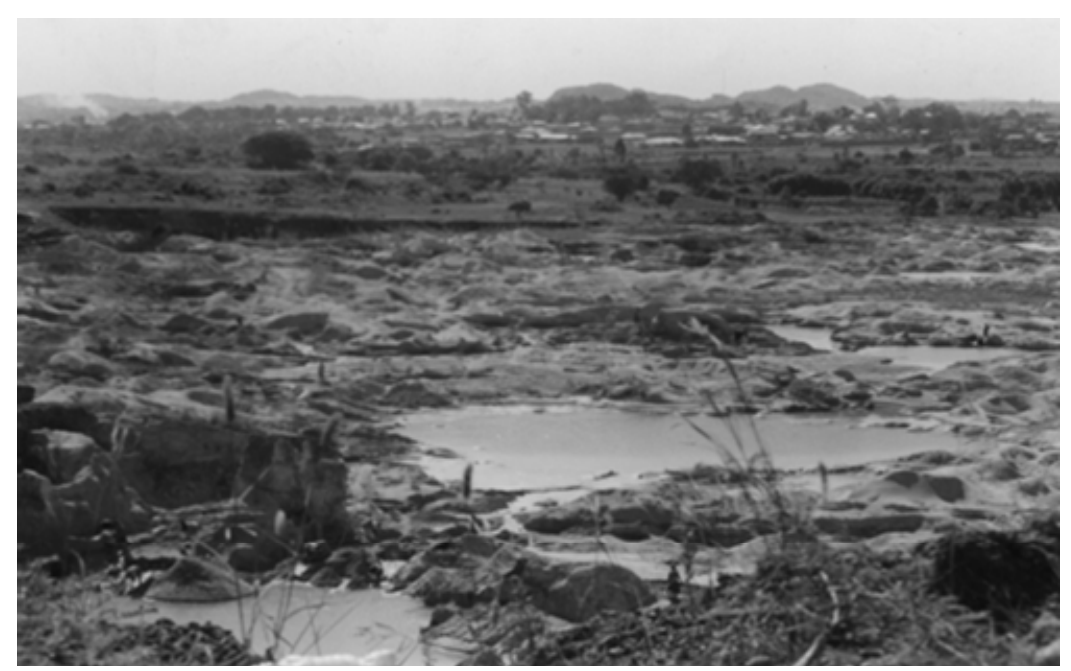

Figure 6. A Degraded Land under Active Mining 